\title{
ANALYSIS OF THE EMPLOYMENT DEFICIT IN THE POST-CRISIS PERIOD
}

\author{
Lavinia Ștefania ȚOȚAN ${ }^{a}$, Corina FRĂSINEANU ${ }^{b}$, Valentin Sorin POPESCU ${ }^{c}$ \\ ${ }^{a},{ }^{b}$ Bucharest University of Economic Studies, Romania \\ ${ }^{c}$ Ministry of National Education, Romania
}

DOI: $10.24818 / \mathrm{IMC} / 2020 / 04.20$

\begin{abstract}
The article presents the evolution of the labor market in the post-crisis period: labor market demand and labor market supply. The employment deficit takes place when the demand of employees in a specific occupation exceeds the supply of employees who are available, qualified and looking for a job. The scope of the paper is to identify the gaps of qualified employees in the activities of national economy.
\end{abstract}

KEYWORDS: demand, employment, supply.

\section{INTRODUCTION}

The determinants of labor supply and demand may derive from economic theories as well as from empirical studies. A detailed analysis of the main factors which influencing the employment deficit is not necessary to make forecasts of the employment deficit, but is the crucial point for defining labor market policies.

When we are analyzing its causes, we must define the concept from the microeconomic perspective (Wilson, 1994). In this case, the deficit must be defined in terms of a slower or persistent increase in labor demand which outperforms the labor market's ability to supply workers (Visco, 2002).

The growth of the economic branches is also very important due to the fact that this composition of the labor demand differs significantly between the economic branches. In the future, we expect that the economic changes to continue, a decline in the agriculture and in the production sectors. Structural changes between economic branches can be caused by several factors (example: demographic changes, changes in consumers' preferences and the international division of labour (Neugart and Schomann, 2002).

Trend resulting from changing consumers' preferences and the general economic climate will also have an impact on the balance between labor demand and supply (Boeri, 2000).

While the trend will be constant for goods and services, other branches will be marked by strong fluctuations. Changes in the international division of labor will also have an impact on the demand for skills in European companies (Boswell, 2004).

Employers currently have difficulties in recruiting employees with a certain qualification necessary to carry out the activities of the companies.

A very important role is also played by the learning process. The employees must improve their knowledge though they are employees in the respective branch of activity (Boswell, 2004). It is important to remember to that this deficit due to inadequacy and its development can be summarized by the Beveridge curve (Meagher et al., 2000).

\footnotetext{
* Corresponding author. E-mail address: lavinia.totan@csie.ase.ro
} 


\section{ANALYSIS OF THE LABOR MARKET DYNAMICS}

\subsection{Analysis of labor market supply in the post-crisis period}

Labor supply is represented by the graduates

From figures 1, we can conclude that the evolution of the middle school graduates between 1990 and 2018 decreases from 335831 persons in 1990 and 172566 persons in 2018. The average decrease was 5830 persons (with 2.26\%).

From figure 2, we can conclude that the evolution of the high schools graduates between 1990 and 2018 decreases from 188732 persons to 148653 persons. The average decreases was 1431 persons (with $0.82 \%$ ). In 2009/2010 was registered tha maximum number of high school graduates (204863 persons).

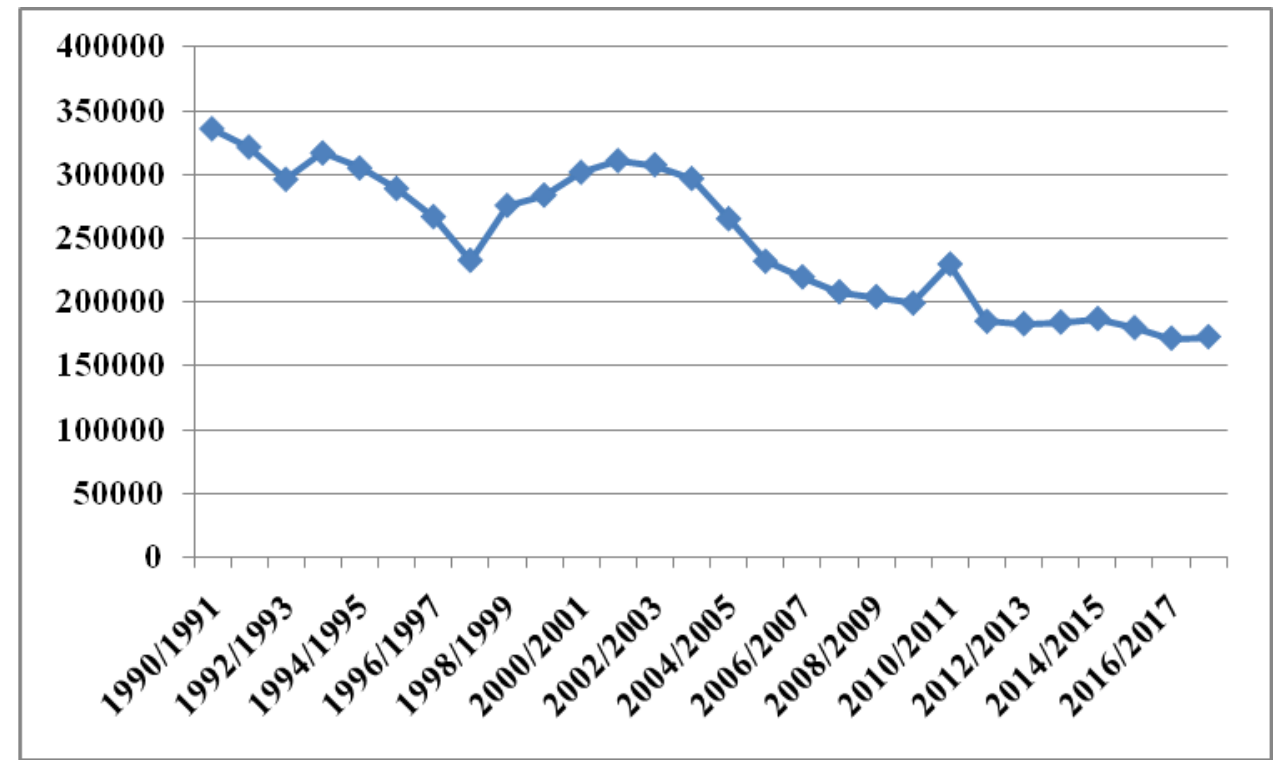

Figure 1. Evolution of the middle school graduates between 1990 and 2018 Source: National Institute of Statistics, 2018-1990

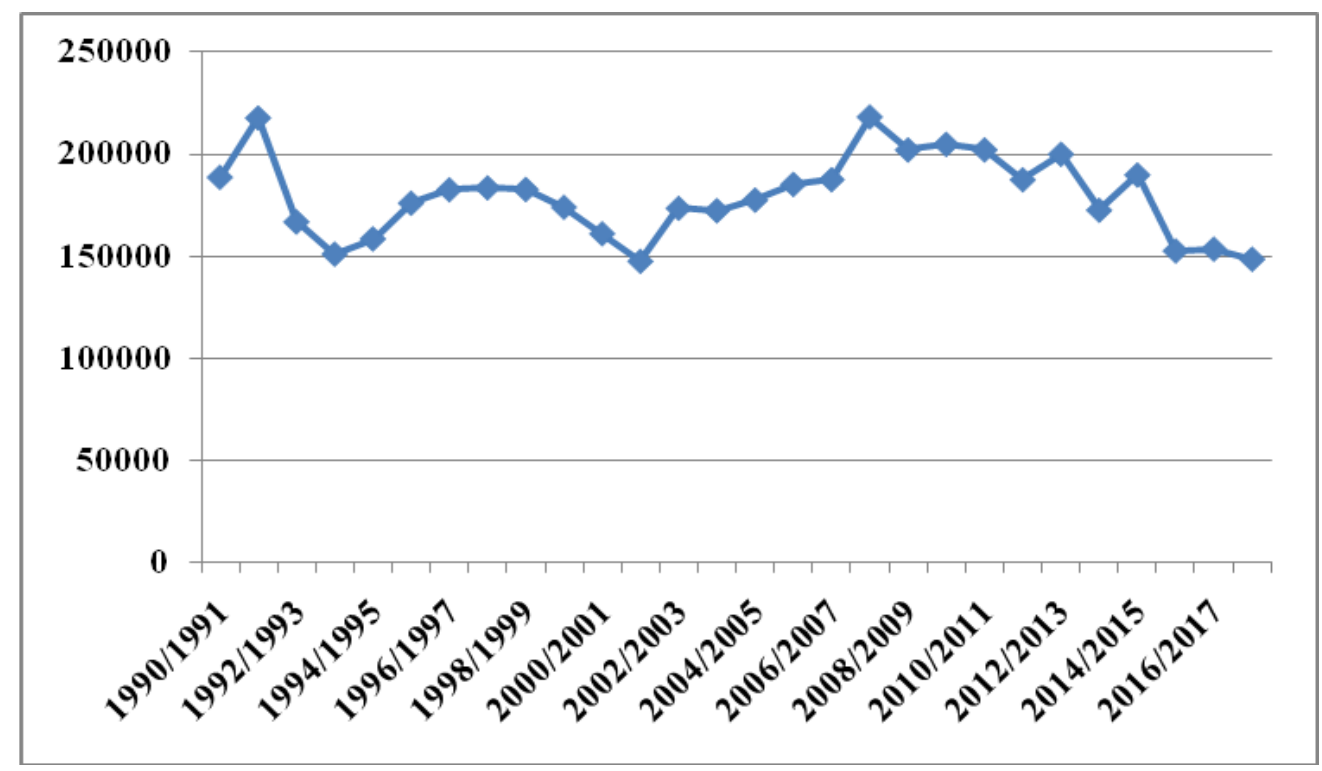

Figure 2. Evolution of the high school graduates between 1990 and 2018 Source: National Institute of Statistics, 2018-1990 
From figure 3, we can conclude that the evolution of the vocational graduates between 1990 and 2018 decreases from 115697 persons in 1990 to 23327 persons in 2018. The maximum number of the vocational graduates was registered in 2004 (152875 persons). The average decrease was 3298 persons (5.37\%).

From figure 4, we can conclude that the evolution of the post-secondary education graduates between 1990 and 2018 increases from 2259 persons (in 1990) and 30985 persons (in 2018).

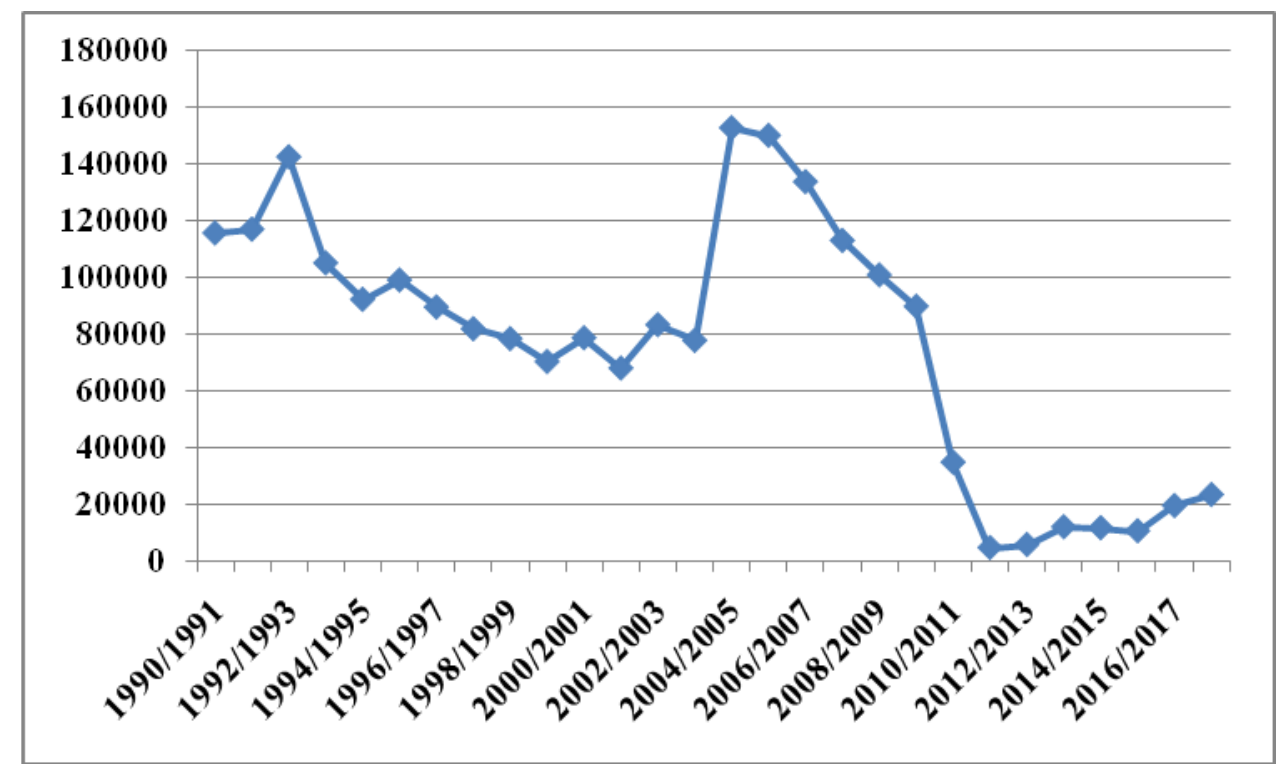

Figure 3. Evolution of the vocational graduates between 1990 and 2018 Source: National Institute of Statistics, 2018-1990

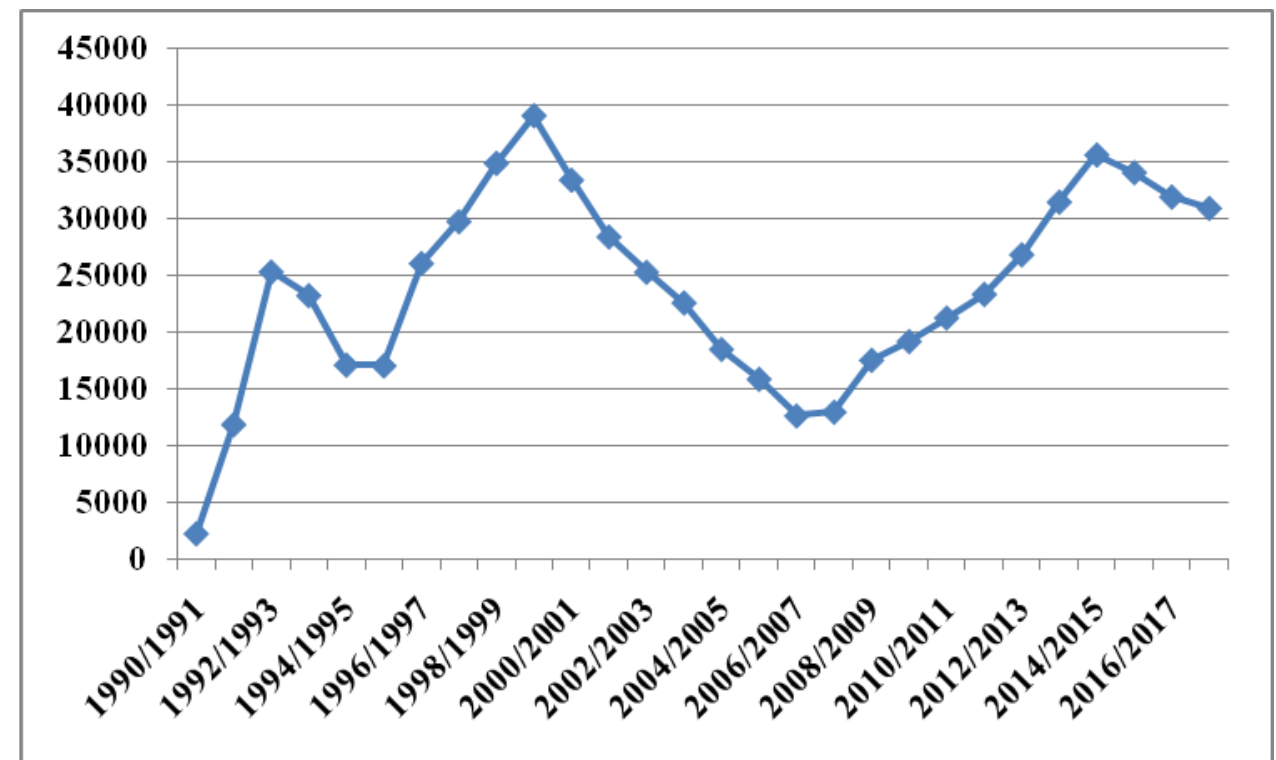

Figure 4. Evolution of the post-secondary education graduates between 1990 and 2018 (persons)

Source: National Institute of Statistics, 2018-1990

The average increase was 1025 persons (9.44\%) between 1990 and 2018. The maximum number of the post-secondary education graduates was registered in 1999(39166 persons). 


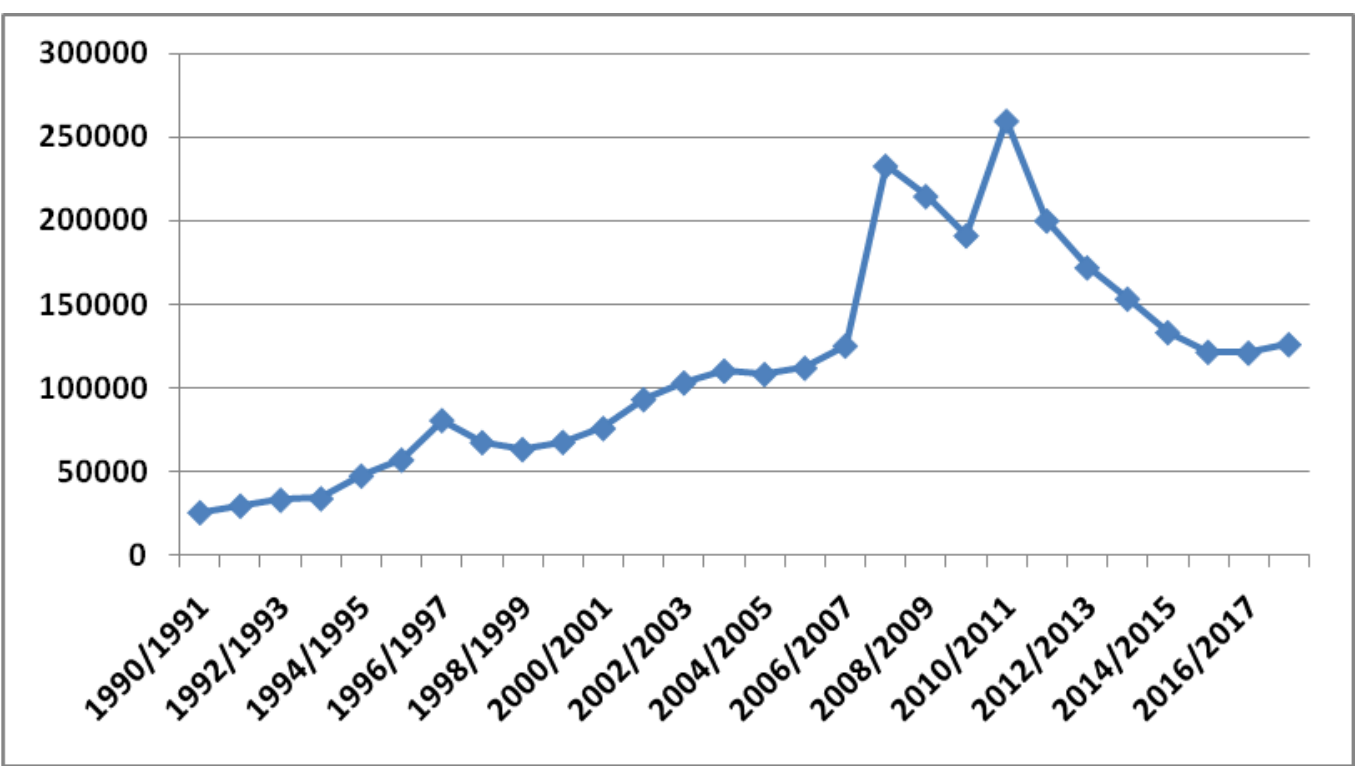

Figure 5. Evolution of the university education graduates between 1990 and 2018 (persons)

Source: National Institute of Statistics, 2018-1990

Table 1. Evolution of high schools graduates (on types of high schools) between 2009 and 2018

\begin{tabular}{|c|c|c|c|c|}
\hline Graduates (persons) & $\mathbf{2 0 0 9 / 2 0 1 0}$ & $\mathbf{2 0 1 2 / 2 0 1 3}$ & $\mathbf{2 0 1 6 / 2 0 1 7}$ & $\mathbf{2 0 1 7 / 2 0 1 8}$ \\
\hline Theoretical high schools and colleges & 42.15 & 38.05 & 51.24 & 51.89 \\
\hline Industrial high schools & 36.12 & 34.38 & 21.63 & 20.56 \\
\hline Agricultural high schools & 1.09 & 1.52 & 1.18 & 1.11 \\
\hline Forestry high schools & 0.42 & 0.50 & 0.55 & 0.63 \\
\hline Agromountain high schools & 0.17 & 0.37 & 0.30 & 0.23 \\
\hline Veterinary high schools & 0.52 & 0.55 & 0.65 & 0.53 \\
\hline Economic and administrative high & & & & \\
schools & 14.34 & 18.47 & 16.62 & 16.60 \\
\hline Pedagogical schools & 0.51 & 0.80 & 1.30 & 1.48 \\
\hline Art high schools & 1.61 & 1.68 & 2.16 & 2.34 \\
\hline Sports high schools & 1.65 & 1.83 & 2.48 & 2.78 \\
\hline Military high schools & 0.14 & 0.17 & 0.21 & 0.24 \\
\hline Theological seminaries & 1.20 & 1.28 & 1.44 & 1.45 \\
\hline Special high schools & 0.07 & 0.41 & 0.25 & 0.17 \\
\hline Total & $\mathbf{1 0 0 . 0 0}$ & $\mathbf{1 0 0 . 0 0}$ & $\mathbf{1 0 0 . 0 0}$ & $\mathbf{1 0 0 . 0 0}$ \\
\hline
\end{tabular}

Source: Own calculations

From figure 5, we can conclude that the number of the university education graduates between 1990 and 2018 increases from 25927 persons in 1990 to 126271 persons in 2018. The average increase was 3583 persons (5.61\%). The maximum number of graduates was registered in 2010 (259740 persons). 


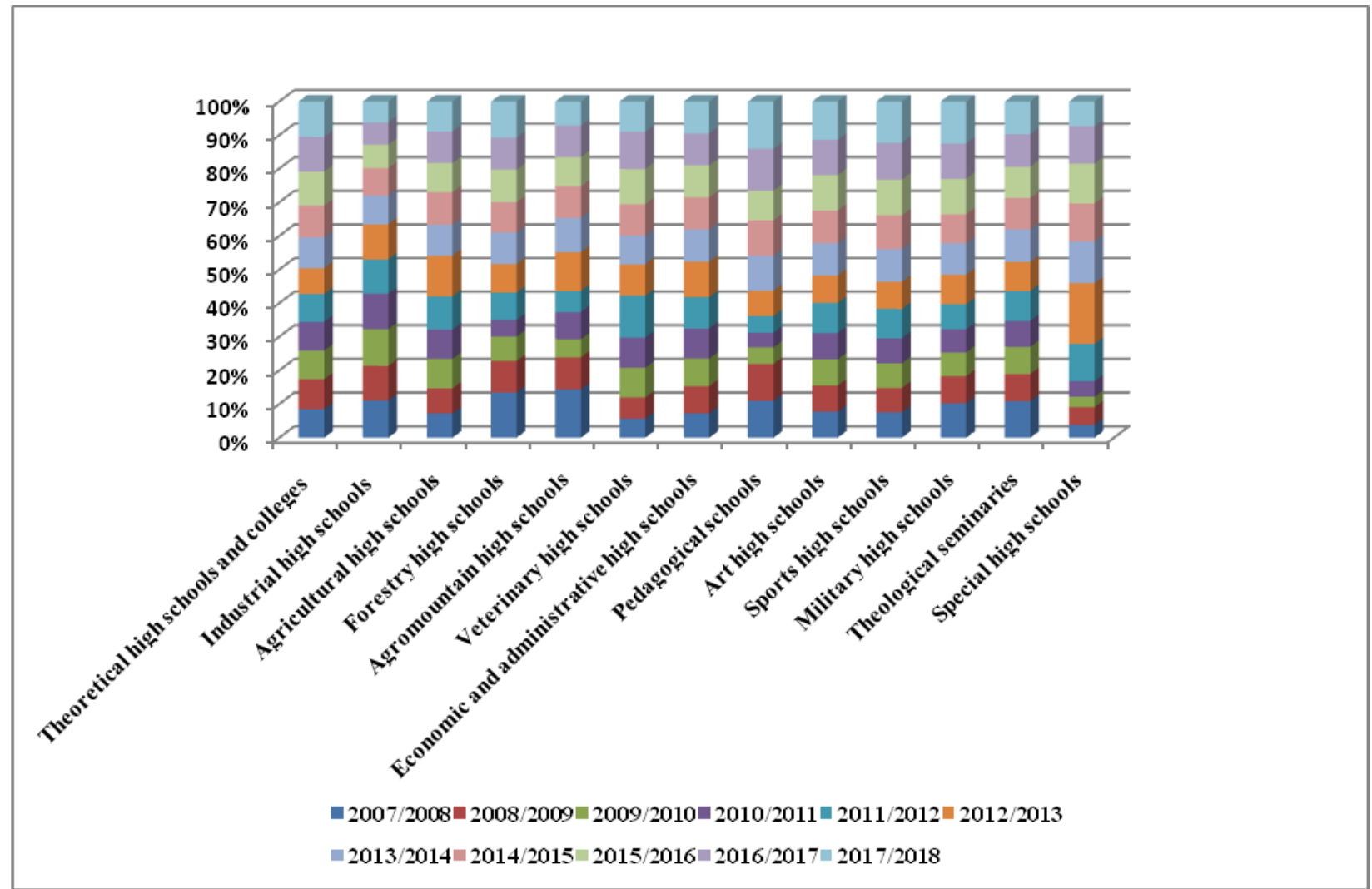

Figure 6. Evolution of high school graduates (after types of high schools) between 1990 and 2018

Source: National Institute of Statistics, 2018-2007

From figure 6, we can conclude that the share of high school graduates by theoretical high schools and colleges increases from $42.15 \%$ in 2007 to $51.89 \%$ in 2017. The share for industrial high schools in the total high school graduates decreases from $36.12 \%$ in 2007 to $20.56 \%$ in 2018 . The share for pedagogical schools in total high schools increases from $0.51 \%$ in 2007 to $1.48 \%$ in 2018 . The share for economic and administrative high schools in total high schools increases from $14.34 \%$ in 2007 to $16.6 \%$ in 2018.

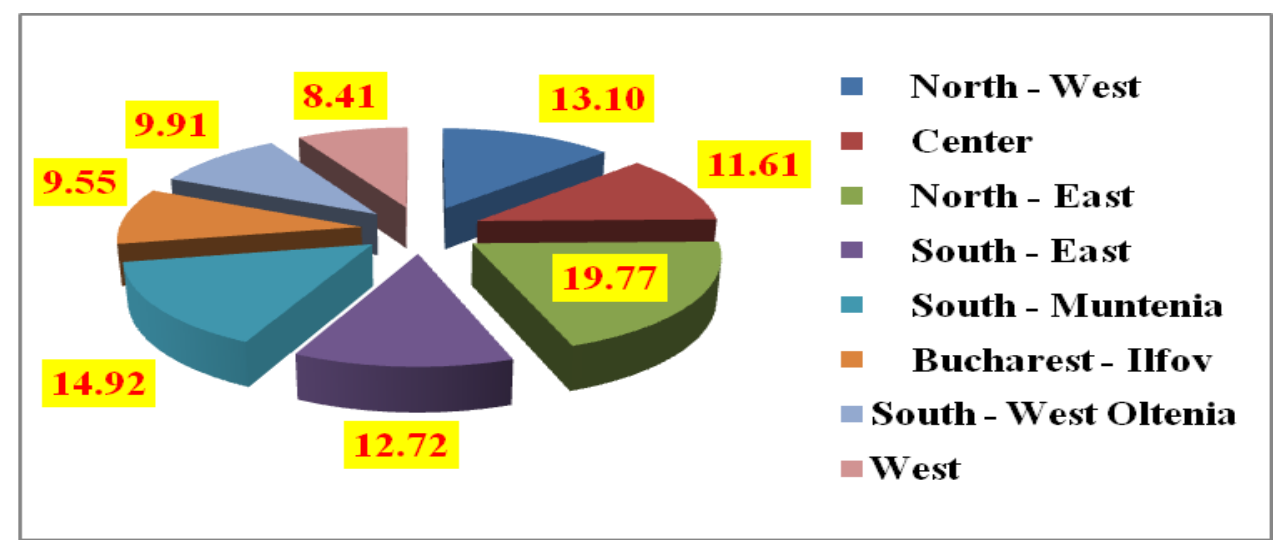

Figure 7. The structure of the middle school graduates in the total number of graduates in 2017/2018 on regions

Source: National Institute of Statistics, 2018

From figure 7, we can conclude that North-West region has $13.1 \%$ the middle school graduates from the total number of graduates in 2017/2018, the Center region has 11.61\%, the North-East 
region $19.77 \%$, the South-Est region $12.72 \%$, the South-Muntenia region has $14.92 \%$ the middle school graduates from the total number of graduates in 2017/2018, the Bucharest-Ilfov region has 9.55\% from the total graduates in 2017/2018, the South-West region has 9.91\% and the West region $8.41 \%$.

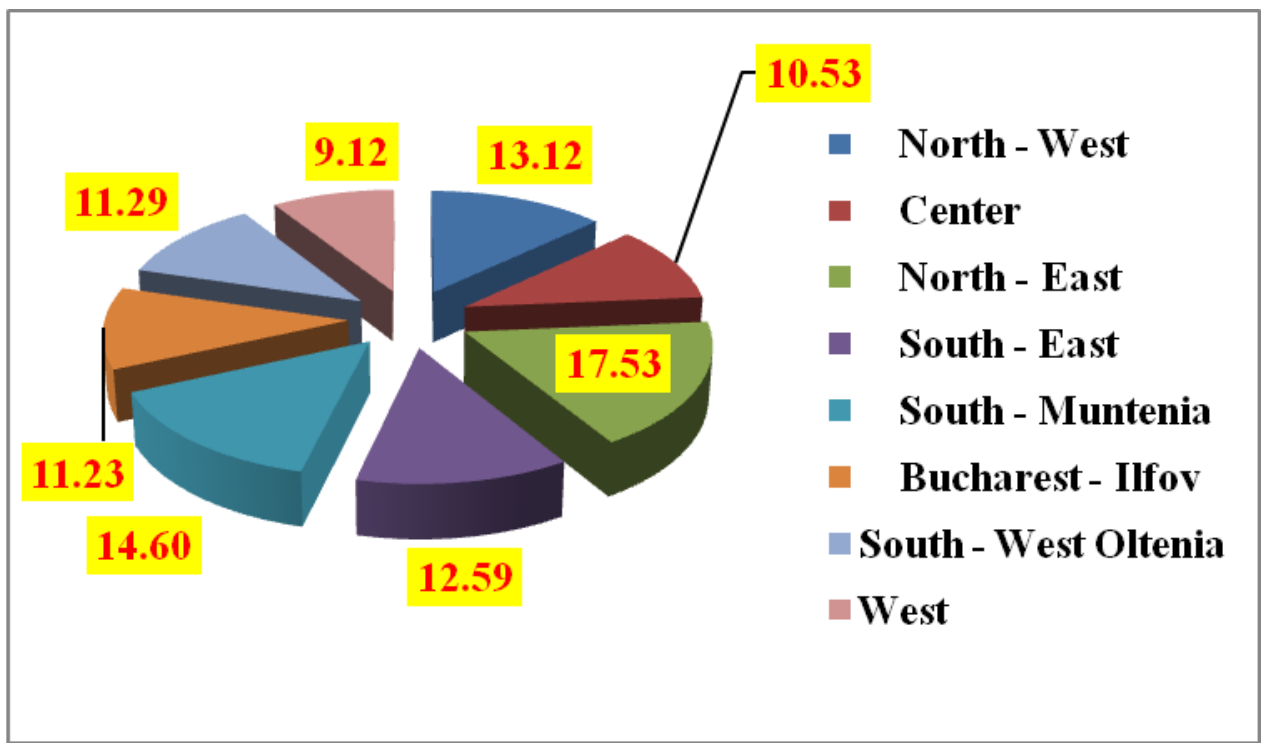

Figure 8. The structure of the high schools graduates in the total number of graduates in 2017/2018 on regions

Source: National Institute of Statistics, 2018

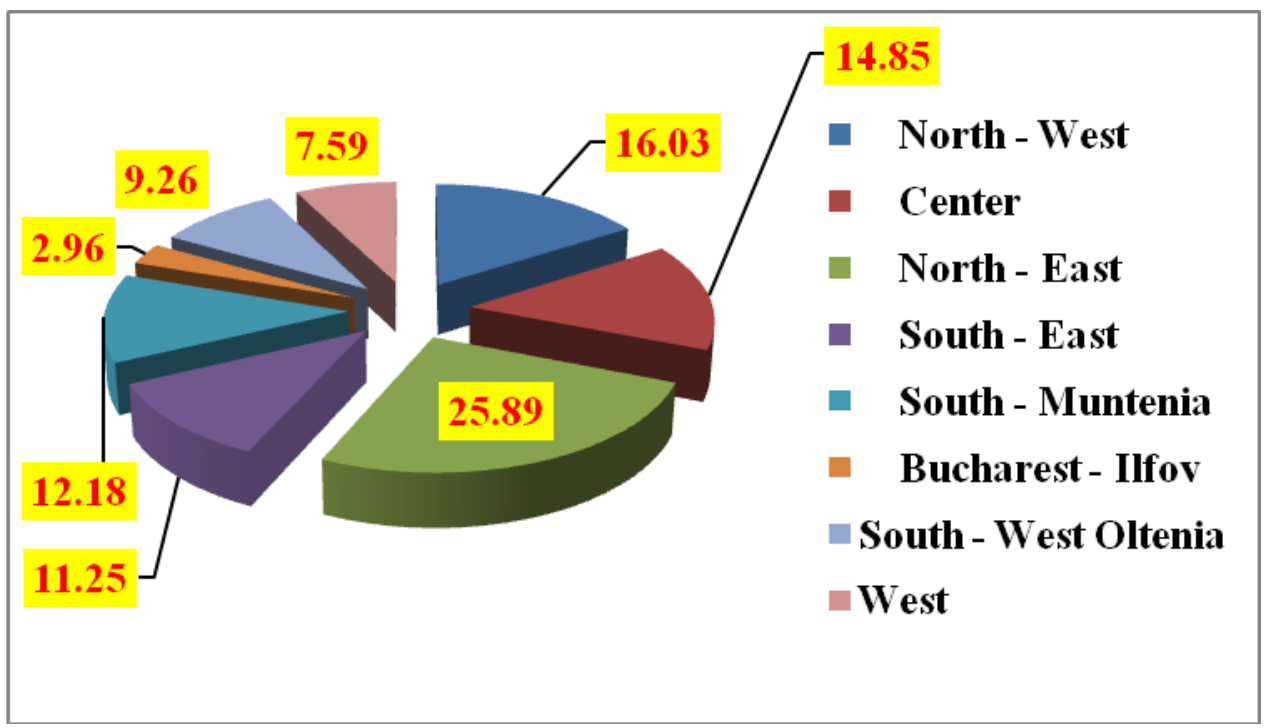

'Figure 9. The structure of the vocational graduates in the total number of graduates in $2017 / 2018$ on regions

Source: National Institute of Statistics, 2018

From figure 8, we can conclude that North-West region has $13.12 \%$ the high school graduates from the total number of graduates in 2017/2018, the Center region has $10.53 \%$, the North-East region $17.53 \%$, the South-Est region $12.59 \%$, the South-Muntenia region has $14.60 \%$ the high school graduates from the total number of graduates in 2017/2018, the Bucharest-Ilfov region has $11.23 \%$ from the total graduates in 2017/2018, the South-West region has $11.29 \%$ and teh West region $9.12 \%$. 


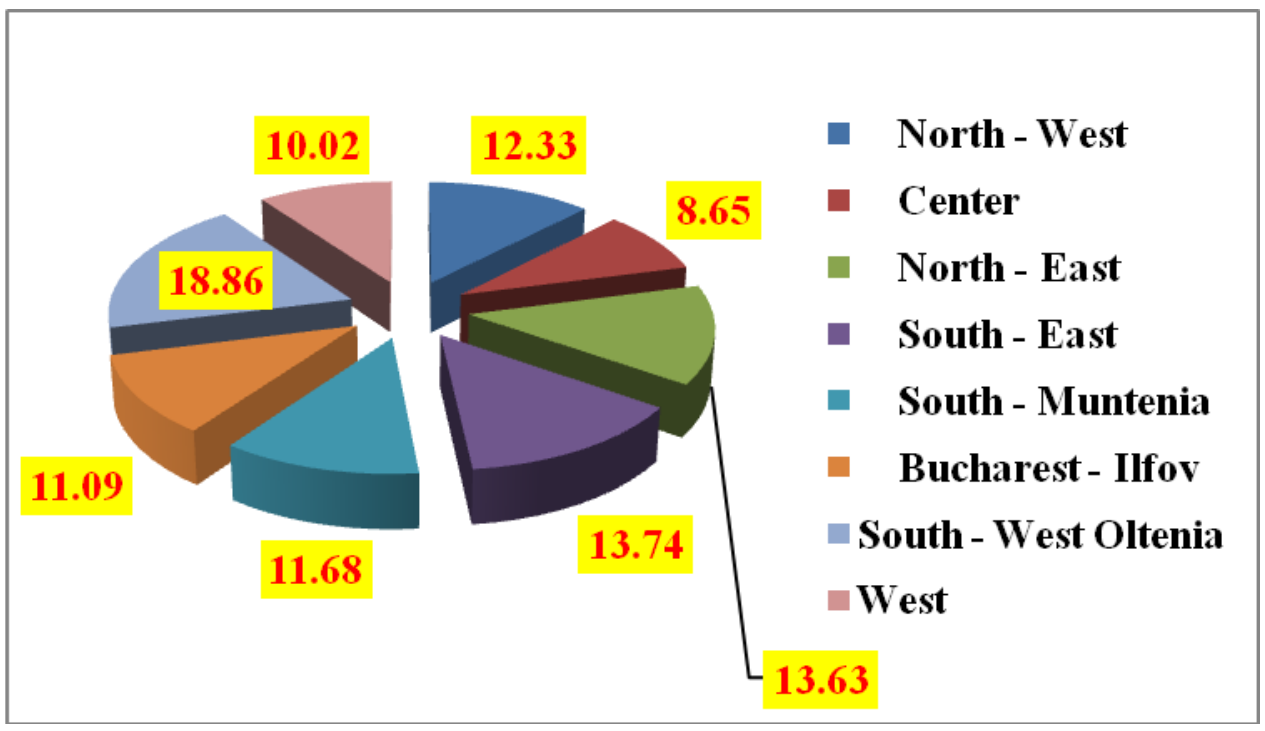

Figure 10. The structure of the post-secondary non-tertiary and foremen graduates in the total number of graduates in 2017/2018 on regions

Source: National Institute of Statistics, 2018

From figure 9, we can conclude that North-West region has $16.03 \%$ the vocational graduates from the total number of graduates in 2017/2018, the Center region has $14.85 \%$, the North-East region $25.89 \%$, the South-Est region 11.25\%, the South-Muntenia region has $12.18 \%$ the vocational graduates from the total number of graduates in 2017/2018, the Bucharest-Ilfov region has 2.96\% from the total graduates in 2017/2018, the South-West region has $9.26 \%$ and the West region $7.59 \%$.

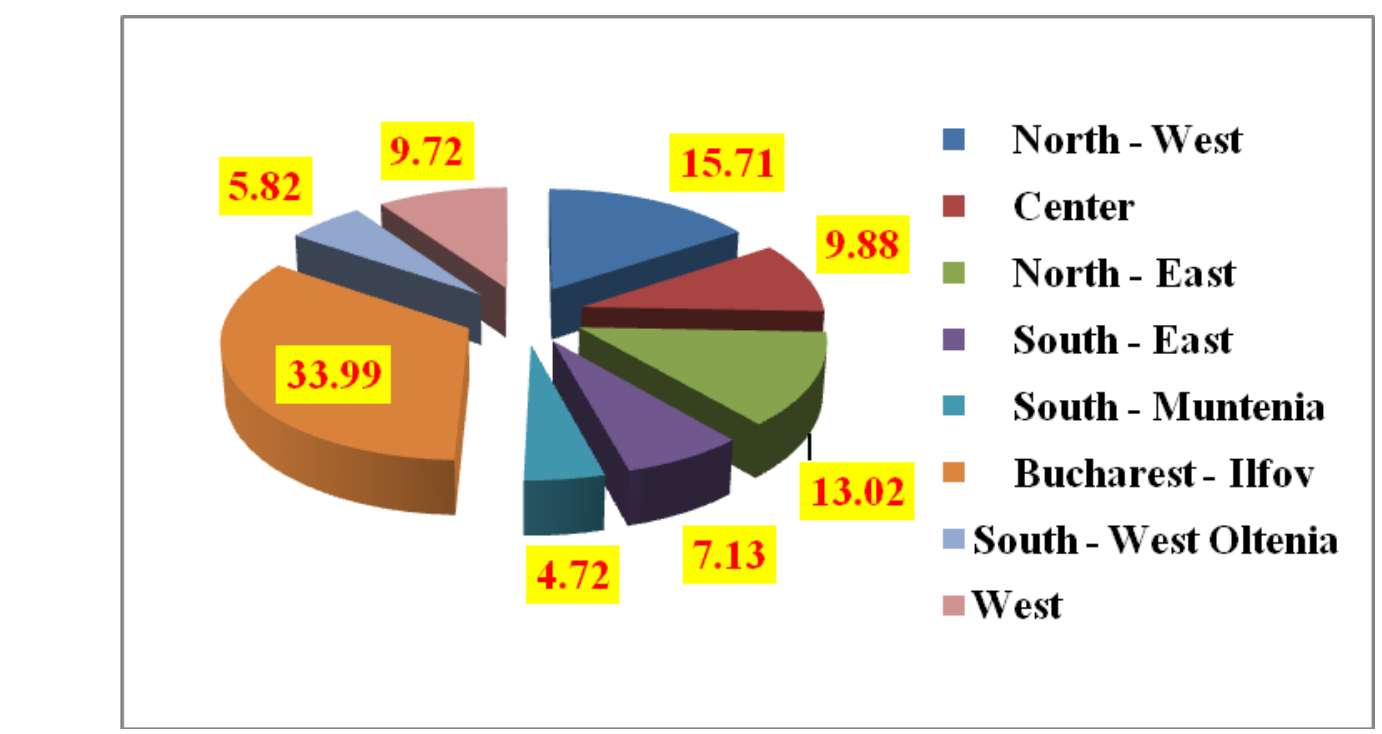

Figure 11. The structure of the tertiary graduates in the total number of graduates in 2017/2018 on regions

Source: National Institute of Statistics, 2018

From figure 10, we can conclude that North-West region has $12.33 \%$ the post-secondary nontertiary and foremen graduates from the total number of graduates in 2017/2018, the Center region has $8.65 \%$, the North-East region $13.63 \%$, the South-Est region $13.74 \%$, the South-Muntenia region has $11.68 \%$ the post-secondary non-tertiary and foremen school graduates from the total number of 
graduates in 2017/2018, the Bucharest-Ilfov region has $11.09 \%$ from the total graduates in 2017/2018, the South-West region has $18.86 \%$ and the West region $10.02 \%$.

From figure 11, we can conclude that North-West region has $15.71 \%$ the tertiary graduates from the total number of graduates in 2017/2018, the Center region has $9.88 \%$, the North-East region $13.02 \%$, the South-Est region $7.13 \%$, the South-Muntenia region has $4.72 \%$ the tertiary graduates from the total number of graduates in 2017/2018, the Bucharest-Ilfov region has 33.99\% from the total graduates in 2017/2018, the South-West region has 5.82\% and the West region $9.72 \%$.

\subsection{Analysis of labor market demand in the post-crisis period}

From figure 12 we can conclude that the evolution of the employment population in Romania between 1997 and 2018 decreases from 10807 thousands persons in 1997 to 8689 thousands persons in 2018. The average decrease was 100 thousands persons (1\%).

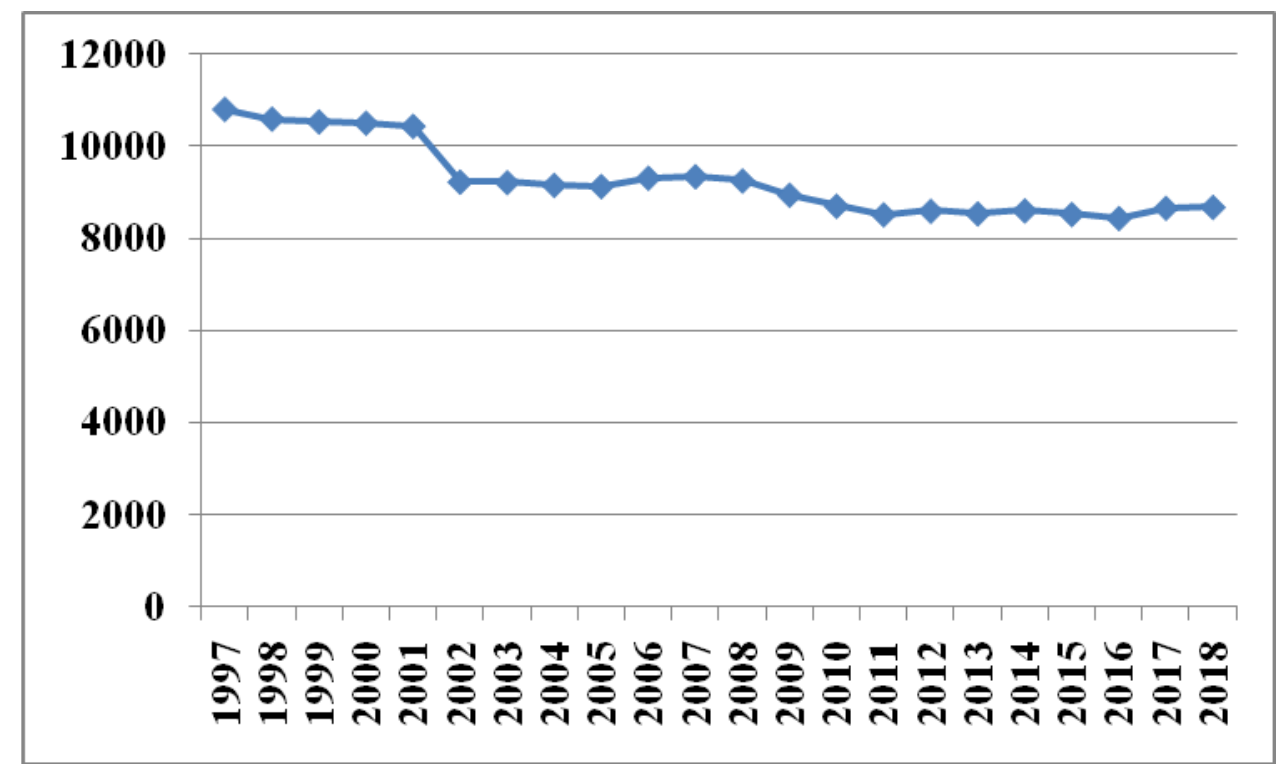

Figure 12. The evolution of employment between 1997 and 2018

Source: National Institute of Statistics, 2018-1997

Figure 13 presents the structure of employment population by educational attainment between 1997 and 2018. The structure of tertiary employment population from the total employment population increases from $17.92 \%$ in 2012 to $20.52 \%$ in 2018.

The structure of medium employment population from the total employment population increases from $59.31 \%$ in 2012 to $60.49 \%$ in 2018.

The structure of low employment population from the total employment population decreases from $22.77 \%$ in 2012 to $18.99 \%$ in 2018.

Figure 15 presents the structure of employment population by activities of national economy between 1997 and 2018. 


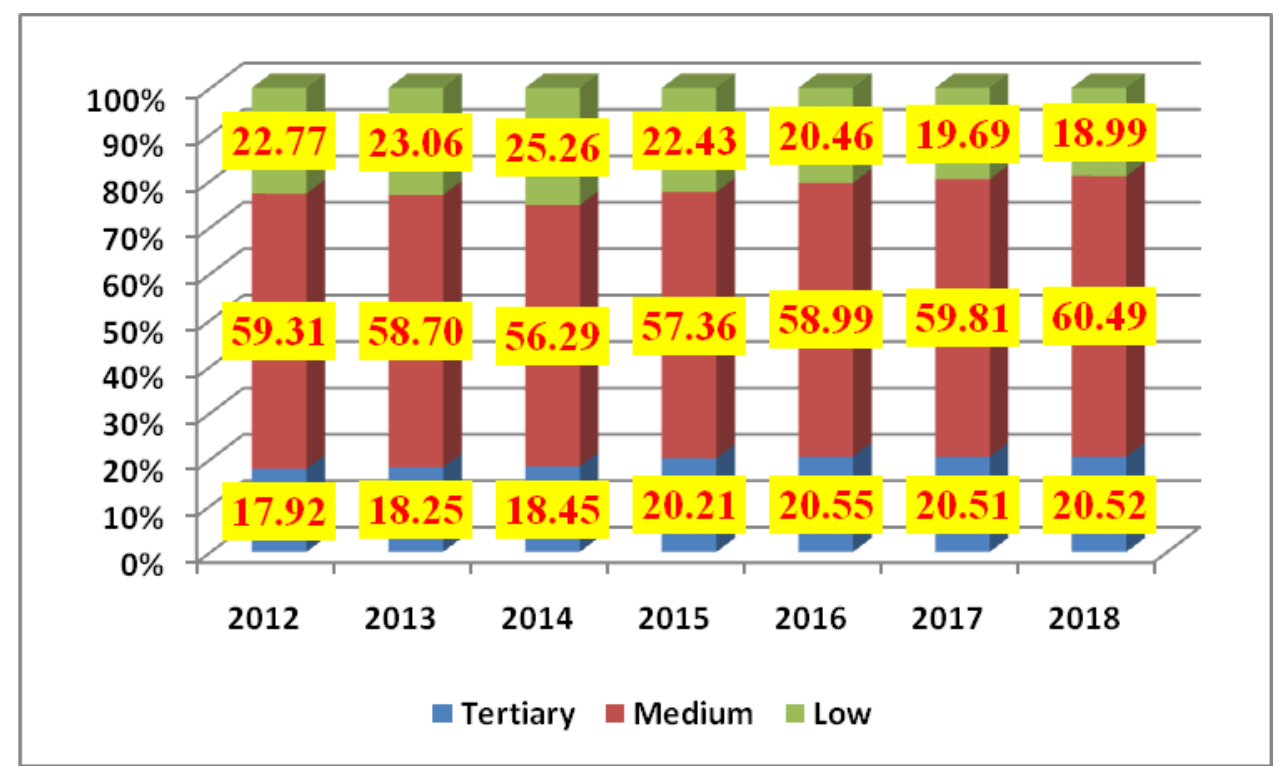

Figure 13. The structure of employment population by educational attainment between 1997 and 2018

Source: National Institute of Statistics, 2018-2012

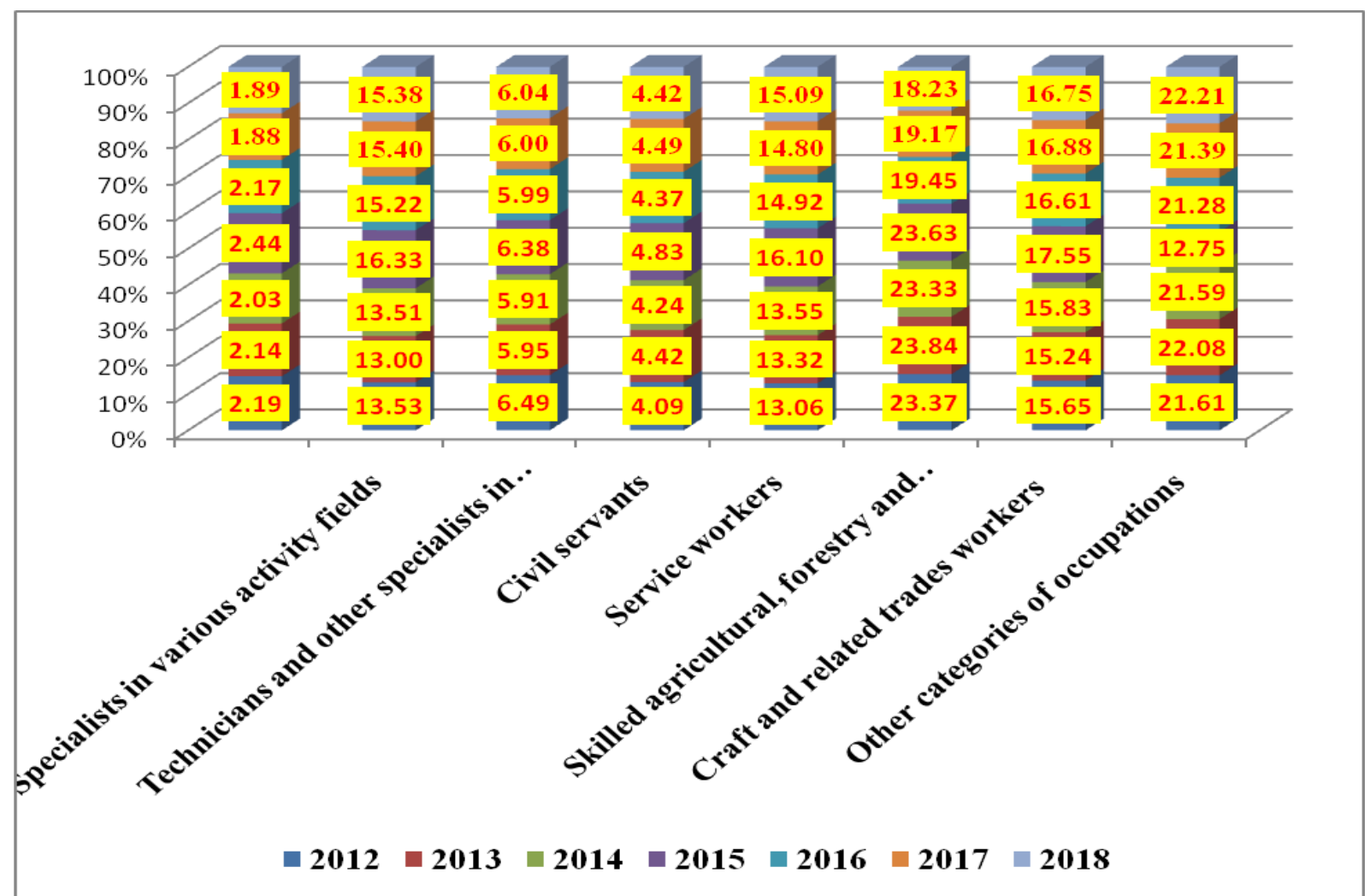

Figure 14. The structure of employment population by occupation group between 1997 and 2018

Source: National Institute of Statistics, 2018-2012 


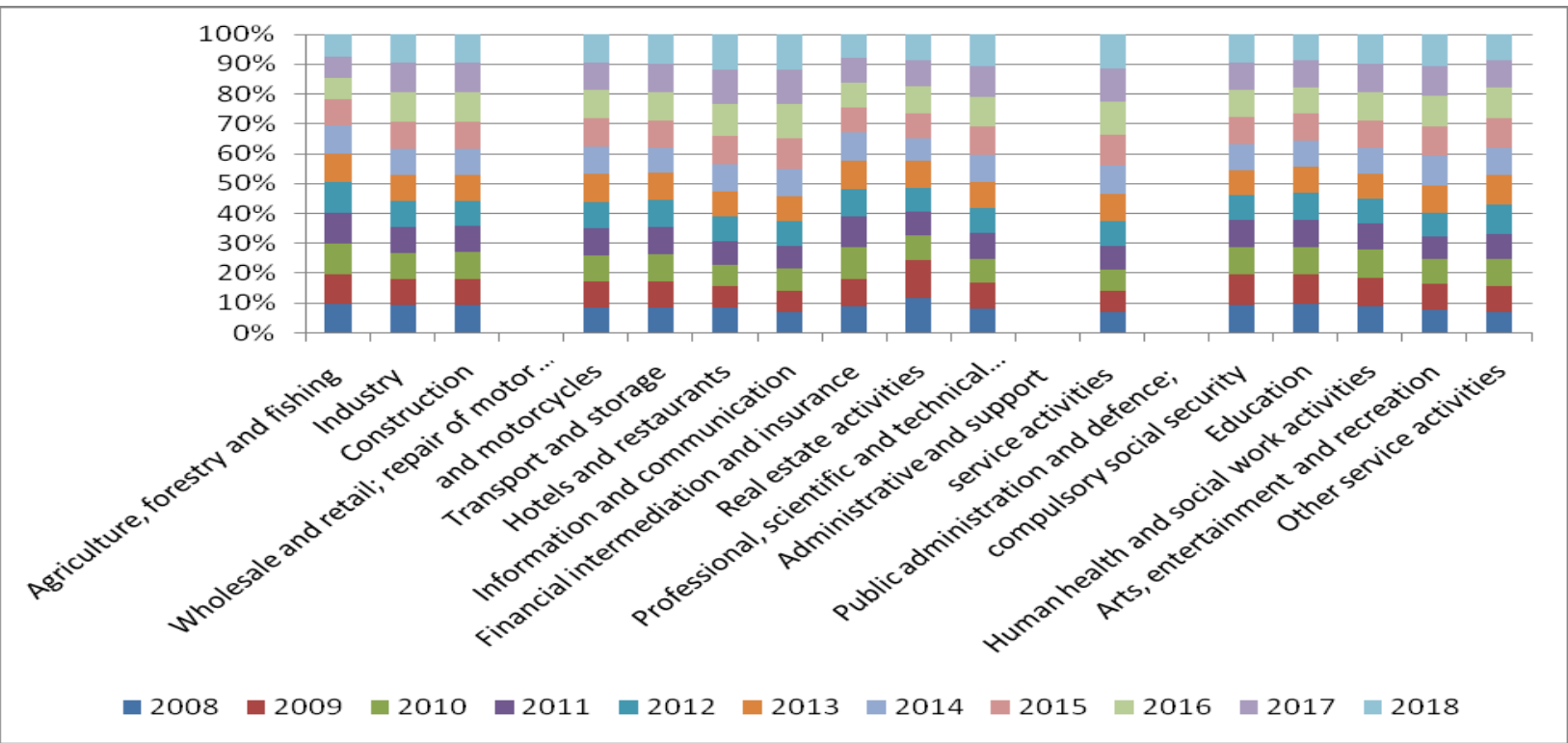

Figure 15. The structure of employment population by activities of national economy between 1997 and 2018

Source: National Institute of Statistics, 2018-2008

Table 2. Structure employment by activity of national economy between 2008 and 2018

\begin{tabular}{|c|c|c|}
\hline Structure of employment (\%) & $\mathbf{2 0 0 8}$ & $\mathbf{2 0 1 8}$ \\
\hline Agriculture, forestry and fishing & 27.52 & 20.92 \\
\hline Industry & 22.65 & 23.16 \\
\hline Construction & 7.91 & 8.12 \\
\hline Wholesale and retail & 13.35 & 14.47 \\
\hline Transport and storage & 4.82 & 5.60 \\
\hline Hotels and restaurants & 1.85 & 2.56 \\
\hline Information and communication & 1.51 & 2.50 \\
\hline Financial intermediation and insurance & 1.34 & 1.20 \\
\hline Real estate activities & 0.54 & 0.40 \\
\hline Professional, scientific and technical & 1.90 & 2.46 \\
\hline activities & 0.00 & 0.00 \\
\hline Administrative and support & 2.48 & 3.96 \\
\hline service activities & 0.00 & 0.00 \\
\hline Public administration and defence; & 2.52 & 2.50 \\
\hline compulsory social security & 4.94 & 4.44 \\
\hline Education & 4.60 & 5.05 \\
\hline Human health and social work activities & 0.71 & 0.96 \\
\hline Arts, entertainment and recreation & 1.37 & 1.69 \\
\hline Other service activities &
\end{tabular}

Source: National Institute of Statistics, 2018-2008

In table 2 is presented the structure of employment population by activities of national economy in 2008 and 2018. The main conclusions are: the structure of employment population in agriculture decreases from $27.52 \%$ in 2008 to $20.92 \%$ in 2018. In industry the structure of employment 
population increases from $22.65 \%$ in 2008 to $23.16 \%$ in 2018. In hotels and restaurants the structure of employment population increases from $1.85 \%$ in 2008 to $2.56 \%$ in 2018 . In education, the structure of employment population decreases from $4.94 \%$ in 2008 to $4.44 \%$ in 2018 .

\section{CONCLUSIONS}

The main results are: the structure of employment population in generally increases ( in hotels and restaurant, in service activities, professional, scientific and technical activities, in transport and storage, in industry, in construction, in wholesale and retail activity. The demand for education will be decrease. The demand for health and for tourism will be increase. The structure of members of legislative bodies decreases from $2.19 \%$ in 2012 to $1.89 \%$ in 2018 . The structure of Specialists in various activity fields increases from $13.53 \%$ in 2012 to $15.38 \%$ in 2018.

The structure of technicians and other specialists in technical field decreases from $6.49 \%$ in 2012 to $6.04 \%$ in 2018. The structure of civil servants increases from $4.09 \%$ in 2012 to $4.42 \%$ in 2018. The structure of service workers increases from $13.06 \%$ in 2012 to $15.09 \%$ in 2018.

\section{REFERENCES}

Boeri, T. \& Brucker, H. (2000). The Impact of Eastern Enlargement on Employment and Wages in the EU Member States. Retrived August 17, 2020, from https://www.frdb.org/be/file/_scheda/files/ec_exsumm_1_5.pdf.

Boswell, C., Stiller, S. \& Straubhaar, T. (2004). Forecasting Labour and Skills Shortages: How Can Projections Better Inform Migration Policies?. Retrieved from https://www.academia.edu/14765353/Forecasting_labour_and_skills_shortages_How_can_ projections_better_inform_labour_migration_policies.

Meagher, G. A., Adams, P. D. \& Horridge, J. M. (2000). Applied General Equilibrium Modelling and Labour Market Forecasting. Center of Policy Studies, Victoria University, Preliminary Paper Nr. IP-76 from https://ideas.repec.org/p/cop/wpaper/ip-76.html.

National Institute of Statistics (2018 - 1990). Romanian Statistical Yearbook. Time Series 19902018. Bucharest.

Neugart, M. \& Schomann, K. (2002). Forecasting Labour Market in OECD Countries: Measuring and Tackling Mismatches. Cornwall: MPG Books.

Visco, I. (2002). Ageing Population Economic Issues and Policy Challenges. In Horst Siebert (Ed) Economic Policy for Aging Society, (pp.9-35). Kiel, Germany: Springer Retrieved from https://books.google.ro/books?hl=ro\&lr=\&id=k7fvYf7976oC\&oi=fnd\&pg=PA9\&dq=Ageing+ Population+Economic+Issues+and+Policy+Challenges\&ots=CuZQtNwDWK\&sig=AK2Y4b8 PPHAwNYdWnhvLYmJ49fk\&redir_esc=y\#v=onepage\&q=Ageing\%20Population\%20Econo mic\%20Issues\%20and\%20Policy\%20Challenges\&f=false

Wilson R. (1994) Modelling and Forecasting the Structure of Employment in the United Kingdom. In: Heijke H. (eds) Forecasting the Labour Market by Occupation and Education (pp.9-35). Dordrecht, Switzerland: Springer. https://doi.org/10.1007/978-94-011-1362-5_2. Retrieved July 17, 2020, from https://link.springer.com/chapter/10.1007\%2F978-94-011-13625_2\#citeas 